\title{
AT1R Blockade and Treatment for Endometrial Cancer
}

\section{Fang-Fang Bi, Qing Yang and $\mathrm{Da} \mathrm{Li}^{*}$}

Department of Obstetrics and Gynecology, Shengjing Hospital, China Medical University, Shenyang, China

We were interested in the recent article entitled "Effect of AT1R knockdown on Ishikawa cell proliferation induced by estrogen [1]". In that research, it is tempting to assume that Angiotensin II Type 1 Receptor (AT1R) can promote the proliferation of estrogen-induced Ishikawa human endometrial cancer cell line.

The Renin-Angiotensin System (RAS) includes AngiotensinConverting Enzyme (ACE), Angiotensin II (Ang II) and AT1R, etc., and plays a critical role in the control of cardiovascular function [2]. Numerous studies in the past several decades have firmly established that RAS blockade prevents the development of cardiovascular disease $[3,4]$. Recently, AT1R has drawn considerable interest, not only in the field of cardiovascular risk but also in several types of gynecological malignancies, such as ovarian cancer $[5,6]$, cervical carcinoma $[5,7]$ and endometrial cancer $[5,8]$. Notably, Shibata et al. showed a correlation between the expression of Ang II and AT1R, and poor disease-free survival of endometrial cancer patients [9]. Similarly, Choi et al. suggested that the AT1R blocker losartan has an antiproliferative effect on endometrial cancer cells [10]. The available data indicate that AT1R blockers may be an effective method of treatment for endometrial cancer, but the mechanisms underlying this response remain to be determined. Although accumulating evidence demonstrates that Ang II-AT1R is a key pathway involved in tumor cell proliferation, angiogenesis and metastasis in many human cancers [5], limited published evidence deciphered the role of AT1R in the progression of endometrial cancer.

Yang et al. attempted to observe the effects of AT1R on the proliferation of human endometrial cancer cell line, which is an interesting idea, but there are still many issues that need to be solved. First, it has been known that estrogens can affect the expression and activity of RAS [11]. As such, two types of endometrial cancer (estrogen-dependent and estrogen-independent) should be studied separately. Second, primary endometrial cancer cells are a suitable biological model to study the effects of AT1R in comparison Ishikawa cell lines. Thirdly, there is no direct evidence that estrogen can promote the proliferation of Ishikawa cells through AT1R, rather than via the estrogen receptor [1]. Although several critical questions remain, the study has provided valuable insight into the relationship between AT1R and endometrial cancer, and may be helpful in predicting the etiology of endometrial cancer.

These data correlate with the increasing evidence that AT1R blockers have tumor-suppressive effects in various experimental models [5]. In addition, AT1R blockers, such as candesartan, valsartan, telmisartan and losartan are effective antihypertensive agents, and may therefore be readily applied in a clinical setting. AT1R blockers may be a novel approach for the treatment of endometrial cancer.

\section{Acknowledgements}

This work was supported by Shenyang science and technology project (No. F12-193-9-11).

\section{References}

1. Yang Q, Su Q, Wang G, Bi F, Sa R (2012) Effect of AT1R knockdown on ishikawa cell proliferation induced by estrogen. Arch Gynecol Obstet 286: 481487.

2. Crowley SD, Coffman TM (2012) Recent advances involving the reninangiotensin system. Exp Cell Res 318: 1049-1056.

3. Probstfield JL, O'Brien KD (2010) Progression of cardiovascular damage: the role of renin-angiotensin system blockade. Am J Cardiol 105: 10A-20A.

4. Sestito A (2011) Hypertension therapy and cardiovascular protection. Effects of angiotensin II receptor block with Valsartan. Eur Rev Med Pharmacol Sci 15: $1247-1255$

5. Ino K, Shibata K, Yamamoto E, Kajiyama H, Nawa A, et al. (2011) Role of the renin-angiotensin system in gynecologic cancers. Curr Cancer Drug Targets 11: 405-411.

6. Ino K, Shibata K, Kajiyama H, Yamamoto E, Nagasaka T, et al. (2006) Angiotensin II type 1 receptor expression in ovarian cancer and its correlation with tumour angiogenesis and patient survival. Br J Cancer 94: 552-560.

7. Kikkawa F, Mizuno M, Shibata K, Kajiyama H, Morita T, et al. (2004) Activation of invasiveness of cervical carcinoma cells by angiotensin II. Am J Obste Gynecol 190:1258-1263.

8. Piastowska-Ciesielska AW, Płuciennik E, Wójcik-Krowiranda K, Bieńkiewicz A Nowakowska M, et al. (2012) Correlation between VEGFR-2 receptor kinase domain-containing receptor (KDR) mRNA and angiotensin II receptor type 1 (AT1-R) mRNA in endometrial cancer. Cytokine.

9. Shibata K, Kikkawa F, Mizokami Y, Kajiyama H, Ino K, et al. (2005) Possible involvement of adipocyte-derived leucine aminopeptidase via angiotensin II in endometrial carcinoma. Tumour Biol 26: 9-16.

10. Choi CH, Park YA, Choi JJ, Song T, Song SY, et al. (2012) Angiotensin I type I receptor and miR-155 in endometrial cancers: synergistic antiproliferative effects of anti-miR-155 and losartan on endometrial cancer cells. Gynecol Oncol 126: 124-131.

11. Maric-Bilkan C, Manigrasso MB (2012) Sex differences in hypertension: contribution of the renin-angiotensin system. Gend Med 9: 287-291.
*Corresponding author: Da Li, Department of Obstetrics and Gynecology, Shengjing Hospital, China Medical University, Shenyang 110004, China, Tel: 86024-96615-42111; Fax: 86-024-83955092; E-mail: leeda@ymail.com

Received January 15, 2013; Accepted January 17, 2013; Published January 20 2013

Citation: Bi FF, Yang Q, Li D (2012) AT1R Blockade and Treatment for Endometria Cancer. Clin Exp Pharmacol 2:115. doi:10.4172/2161-1459.1000115

Copyright: (c) 2012 Bi FF, et al. This is an open-access article distributed under the terms of the Creative Commons Attribution License, which permits unrestricted use, distribution, and reproduction in any medium, provided the original author and source are credited. 